\title{
Staphylococcus carnosus: from starter culture to protein engineering platform
}

\author{
John Löfblom ${ }^{1}$ (1) $\cdot$ Ralf Rosenstein $^{2} \cdot$ Minh-Thu Nguyen $^{2} \cdot$ Stefan Ståhl $^{1}$ • \\ Friedrich Götz ${ }^{2}$
}

Received: 3 July 2017 / Revised: 8 September 2017 / Accepted: 11 September 2017 /Published online: 2 October 2017

(C) The Author(s) 2017. This article is an open access publication

\begin{abstract}
Since the 1950s, Staphylococcus carnosus is used as a starter culture for sausage fermentation where it contributes to food safety, flavor, and a controlled fermentation process. The long experience with $S$. carnosus has shown that it is a harmless and "food grade" species. This was confirmed by the genome sequence of S. carnosus TM300 that lacks genes involved in pathogenicity. Since the development of a cloning system in TM300, numerous genes have been cloned, expressed, and characterized and in particular, virulence genes that could be functionally validated in this non-pathogenic strain. A secretion system was developed for production and secretion of industrially important proteins and later modified to also enable display of heterologous proteins on the surface. The display system has been employed for various purposes, such as development of live bacterial delivery vehicles as well as microbial biocatalysts or bioadsorbents for potential environmental or biosensor applications. Recently, this surface display system has been utilized for display of peptide and protein libraries for profiling of protease substrates and for generation of various affinity proteins, e.g., Affibody molecules and $\mathrm{scFv}$ antibodies. In addition, by display of fragmented antigen-encoding genes, the surface expression system has been successfully used for epitope mapping of
\end{abstract}

Stefan Ståhl

ssta@kth.se

Friedrich Götz

friedrich.goetz@uni-tuebingen.de

1 Division of Protein Technology, School of Biotechnology, KTH-Royal Institute of Technology, AlbaNova University Center, Roslagstullsbacken 21, 10691 Stockholm, Sweden

2 Microbial Genetics, Interfaculty Institute of Microbiology and Infection Medicine and Infection Medicine (IMIT), University of Tübingen, Auf der Morgenstelle 28, 72076 Tübingen, Germany antibodies. Reviews on specific applications of $S$. carnosus have been published earlier, but here we provide a more extensive overview, covering a broad range of areas from food fermentation to sophisticated methods for protein-based drug discovery, which are all based on S. carnosus.

Keywords Bacterial surface display $\cdot$ Combinatorial protein engineering $\cdot$ Epitope mapping $\cdot$ Food fermentation $\cdot$ Starter culture $\cdot$ Virulence factors

\section{Introduction}

This review article is unique in its nature in that it describes the use of the food grade Gram-positive bacterium, Staphylococcus carnosus, evolving over several decades, from being an important strain in food fermentation (Götz 1990c) to becoming a versatile and powerful microbial tool in modern microbiology and biotechnology. When the genome sequence was deciphered (Rosenstein and Götz 2010; Rosenstein et al. 2009), the different characteristics of $S$. carnosus were better understood, and as will be described, its non-pathogenic nature made it suitable for characterization of virulence factors. The development of a host-vector system for efficient and secreted recombinant production inspired the development of also a surface display system for $S$. carnosus. The use of these systems in a wide variety of application areas will be reviewed.

\section{S. carnosus as a starter culture}

Some of the most well-investigated staphylococcal species (e.g., $S$. aureus) are pathogens. However, like many other genera, Staphylococcus is composed of many species (>40) with a vast 
diversity, of which only few are associated with pathogenicity. The majority has never been associated with infection, and some species are even used as starter cultures in sausage fermentation (Götz et al. 2006). The first reports on using $S$. carnosus in sausage fermentation came in the 1950s (Lerche and Sinell 1955; Niinivaara and Pohja 1956). At that time, they were regarded as micrococci, a group of Gram-positive cocci that are facultative anaerobic and catalase-positive. However, a systematic analysis of the starter cultures in various fermented dry sausages revealed that most of these micrococci were incorrectly classified and are in fact $S$. carnosus (Schleifer and Fischer 1982). S. carnosus and S. xylosus are the two main staphylococcal species worldwide that are used as starter cultures in food fermentation, either alone or in combination with defined lactobacilli or other microorganisms. Starter cultures protect the food from undesirable bacteria and make the fermentation process more reliable. They also suppress food spoilage and poisoning by unwanted microorganisms and the whole fermentation process can be better controlled. S. carnosus has several functions during the ripening process of dry sausage (Barriere and Leroy-Setrin 2001; Corbiere Morot-Bzot et al. 2007; Liepe and Porobic 1983); nitrate is reduced to nitrite which, together with myoglobin, forms the red colored nitrosomyoglobin (Neubauer and Götz 1996; Götz 1990c). Subsequently, nitrite is further reduced to ammonia which leads to regeneration of $\mathrm{NAD}^{+}$that is needed for glycolysis (Neubauer et al. 1999). S. carnosus also contributes to flavor and to detoxification of hydrogen peroxide that is produced by lactobacilli (Barriere and Leroy-Setrin 2001). Because of its use as a starter culture since the 1950s, S. carnosus is regarded as a "food grade" species (Fig. 1a).

\section{Dissimilatory nitrate fermentation}

Beside flavor, one of the main functions of $S$. carnosus as a starter culture is its ability to reduce nitrate and nitrite. Nitrate and/or nitrite are curing agents that play a decisive role in obtaining the specific sensory properties, stability, and hygienic safety of products such as fermented sausages, ham, and more recently, emulsion type of sausages (Hammes 2012). The intermediary presence of nitrite is important as it prevents the growth of food-spoiling bacteria such as Clostridium. On the other hand, at the end of the fermentation process, both nitrate and nitrite should be decreased below a certain threshold level. As many lactobacilli are unable to reduce nitrate, $S$. carnosus has an important function in the process. In S. carnosus, the reduction of nitrate to ammonia involves several steps (Fig. 1b) (Neubauer and Götz 1996): (i) nitrate is taken up and reduced to nitrite, and nitrite is subsequently excreted, (ii) after depletion of nitrate, the externally accumulated nitrite is taken up by the cells and reduced to ammonia, which again is excreted into the medium. The nitrate reduction by the nitrate reductase is connected with energy gain and is therefore also referred to as "anaerobic respiration" or "dissimilatory nitrate reduction" (Fast et al. 1996; Fedtke et al. 2002). The nitrate reductase is a membranebound enzyme, whereas nitrite reductase is a cytosolic enzyme involved in NADH reoxidation (Neubauer et al. 1999; Pantel et al. 1998). The expression of the corresponding genes is only possible under anaerobic growth conditions and in the presence of nitrate. The mechanism of oxygen repression is based on a three-component system, NreABC (Schlag et al. 2008). NreB is an oxygen-sensing histidine protein kinase with an O-labile ironsulfur cluster of the FNR type (Kamps et al. 2004; Müllner et al. 2008). NreA functions as a nitrate receptor (Niemann et al. 2014), which together with NreB forms a nitrate-oxygen sensor complex (Nilkens et al. 2014). NreC is phosphorylated by NreB and the phospho-NreC acts as a response regulator that specifically binds to a guanine-cytosine (GC)-rich palindromic sequence to enhance transcription initiation of all operons involved in nitrate/nitrate metabolism (Fedtke et al. 2002).

\section{Characterization of the genome of $S$. carnosus TM300}

The 2.56-Mbp genome of S. carnosus TM300 is relatively different from other sequenced genomes of this genus. It is small compared with other genomes and it has the highest GC content (34.6\%) of all sequenced staphylococcal species (Rosenstein and Götz 2010; Rosenstein et al. 2009). Another peculiarity is that the ori and ter regions are asymmetrically arranged with the replichores I (1.05 Mbp) and II (1.5 Mbp) (Fig. 2a). Such an asymmetry could have arisen by a large deletion near the oriC. Our experience with gene cloning and expression in S. carnosus showed that we normally have no trouble with genetic instability. This positive quality could be due to the absence of mobile elements such as plasmids, IS elements, transposons, or STAR elements. Furthermore, the number of repeat sequences has markedly decreased suggesting a comparatively high stability of the genome. In comparison, S. aureus and S. epidermidis strains have numerous such elements and repeat sequences.

Genome analysis revealed that the main pathways are present, although some genes are truncated. This is probably due to the nutrient-rich habitat, which makes some biosynthesis functions superfluous. The latter is particularly important for the bacteria to tolerate the high osmolality in sausage meat. The genome also lacks most of the toxins typical of $S$. aureus as well as genes involved in biofilm formation and adherence to host cells and matrix proteins (Rosenstein and Götz 2010; Rosenstein et al. 2009). While pathogenic species such as S. aureus are completely resistant to lysozyme, S. carnosus and other non-pathogenic species are sensitive to lysozyme, which is produced by mammalians in response to a bacterial infection. The reason for the high lysozyme resistance in $S$. aureus is due to the presence of the peptidoglycan Oacetyltransferase (OatA) that modifies the peptidoglycan in 
Fig. 1 Application of S. carnosus in food technology. a $S$. carnosus is used as starter culture for sausage fermentation where dissimilatory nitrate/nitrite b Steps in dissimilatory nitrate/ nitrite reduction in $S$. carnosus under anaerobic conditions. (1) Nitrate is taken up by the nitrate transporter (NarT). (2) It is reduced to nitrite by nitrate reductase. (3) Nitrite is excreted and accumulates in the supernatant until nitrate is almost completely consumed. (4) Nitrite is taken up again and is $((5))$ intracellularly reduced to ammonia by the NADHdependent nitrite reductase. (6) Ammonia is excreted leading to mild alkalization of the environment reduction plays an important role.

a

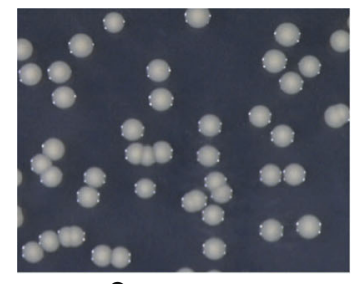

S. carnosus

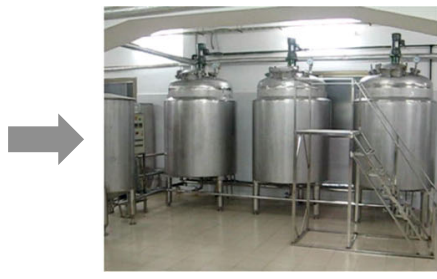

Fermentation



Products b

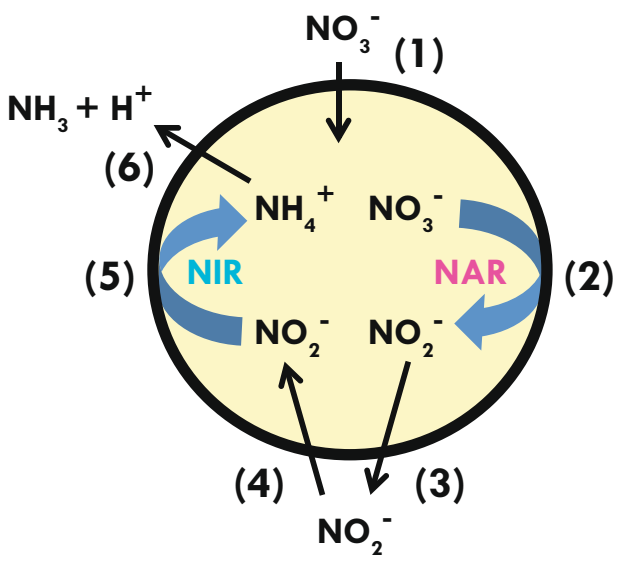

such a way that lysozyme binding is affected (Bera et al. 2005). S. carnosus and other non-pathogenic species lack the oatA gene (Bera et al. 2006). In conclusion, the lack of toxins, hemolysins, many of the adherence proteins, capsule genes, the presence of an unusual high number of truncated genes, and the lack of the peptidoglycan O-acetyltransferase (OatA) underscore the non-pathogenic status of $S$. carnosus.

The natural habitat of $S$. carnosus is still not known today and it has never been associated with pathogenicity. However, its close phylogenetic relationship with $S$. piscifermentans, which is associated with marine fish, suggests that S. carnosus comes from a similar biotope (Probst et al. 1998; Tanasupawat et al. 1992). Although the ecological niche of $S$. carnosus and its related species is unclear, we assume that $S$. carnosus is well equipped to live in a milieu together with Gram-negative bacteria such as Pseudomonas. For example, co-cultivation studies of $S$. carnosus with Pseudomonas aeruginosa, an opportunistic pathogen, revealed that $P$. aeruginosa was unable to suppress the growth of $S$. carnosus, but it massively suppressed the growth of $S$. aureus. $P$. aeruginosa and related species produce a number of respiratory inhibitors like pyocyanin (Hassan and Fridovich 1980), hydrogen cyanide (Castric 1975), and a mixture of quinoline $N$-oxides (Machan et al. 1992). While $S$. aureus, $S$. epidermidis, or $S$. saprophyticus are sensitive to these respiratory inhibitors, $S$. carnosus and S. piscifermentans are resistant (Voggu et al. 2006). The resistance is due to the $c y d A B$ genes that encode a pyocyanin and cyanide resistant cytochrome $b d$ quinol oxidase. In $S$. aureus and other pathogenic species, the cytochrome $b d$ quinol oxidase does not cause resistance (Voggu et al. 2006). It has been shown that in $S$. aureus, the subunit B was altered in such a way that it became sensitive. We assume that $S$. aureus and other pathogenic staphylococcal species rarely come in contact with Pseudomonas and that they have lost the cyanide resistance function by successive mutations in the $c y d B$ gene, a process referred to as "micro evolution" (Voggu et al. 2006). The $c y d A B$ operon is also found in Escherichia coli where it is referred to as a cytochrome $d$ oxidase complex, which is particularly active under oxygen limited conditions (Cotter et al. 1997). We assume that $S$. carnosus and related species live in an environment that is also occupied by Pseudomonas and other Gram-negative bacteria and that they have evolved to resist cyanide and pyocyanin to be able to co-exist with Pseudomonas. As for $S$. aureus, there was probably no need to compete with Pseudomonas, and the $c y d B$ gene was degenerated to cyanide-sensitive respiration.

\section{S. carnosus as a valuable tool to analyze virulence functions}

The lack of most virulence factors makes $S$. carnosus a suitable model organism to study pathogenicity factors from pathogenic staphylococcal species. Numerous invasion factors and matrix-binding proteins have been 
a

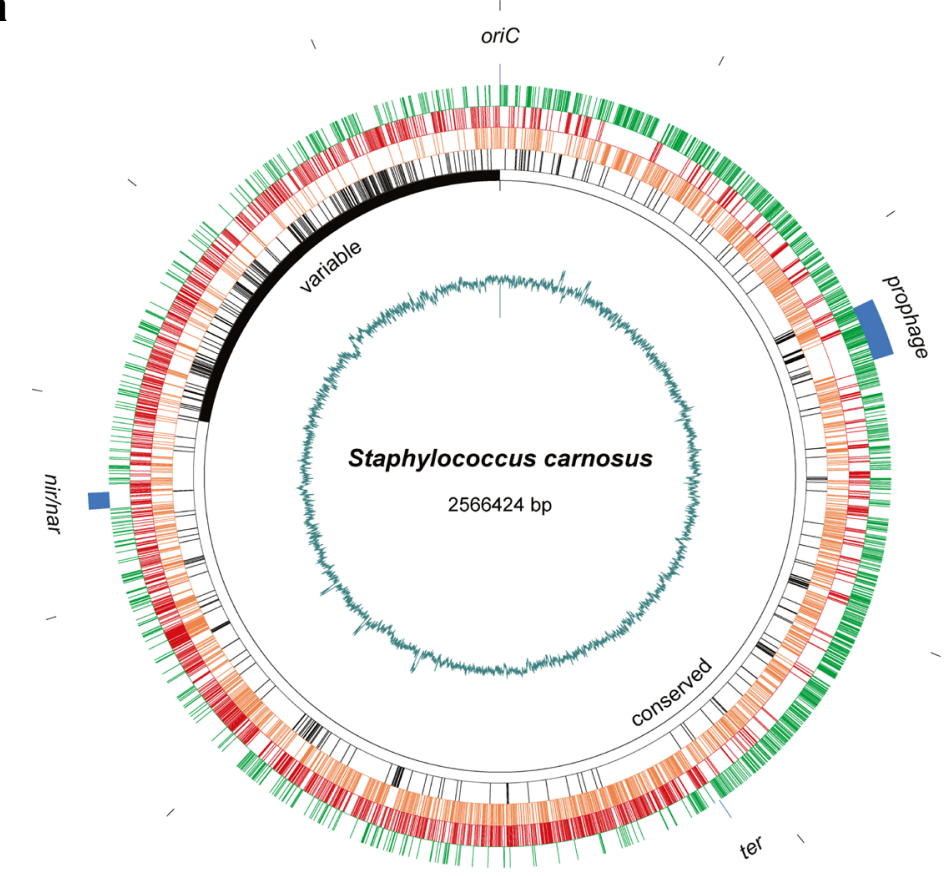

b



Fig. 2 Illustration of $S$. carnosus genomic map and protein construction for secretion. a Genomic map of $S$. carnosus. The green circle represents genes located in the upper strand; the red circle indicates genes from the lower strand. Orange dashes show genes that are conserved within the staphylococci, while the black dashes correspond to genes that are specific for $S$. carnosus TM300. The extension of the conserved core region of the genome is shown by the open black circle; the variable region with an accumulation of species-specific genes is located next to the origin of replication (oriC) and indicated as filled black segment. Note that the point of termination replication (ter) is located asymmetrically with respect to oriC. The blue segments show the positions of a prophage

expressed in $S$. carnosus, to unravel and to prove their functions. For example, unlike $S$. aureus, S. carnosus has no fibronectin-binding proteins and therefore, the function of heterologous-expressed proteins and their role in binding to other matrix proteins or role in host cell invasion has been verified and studied in S. carnosus (Agerer et al. 2005; Grundmeier et al. 2004; Kerdudou et al. 2006; Sinha et al. 2000). The proof that the extracellular adherence protein (Eap) from $S$. aureus enhances host cell internalization was carried out in $S$. carnosus (Haggar et al. 2003). The broad-spectrum binding and the genes responsible for nitrite and nitrate reduction (nir/nar), respectively. A GC plot showing local deviations in GC content is presented on the innermost circle. The scale is shown in the outermost circle with the ticks indicating every 0.2 million bases. b SHL-based secretion signals for heterologous secretion of proteins (secretion construct). The signal peptide (SP) and the propeptide (PP) of SHL (Staphylococcus hyicus lipase) is used to secrete other proteins (protein $\mathrm{X}$ ) into the supernatant in high amounts. The PP part can be cleaved off by a specific protease that cleaves at the proteolytic cleavage site introduced between PP and protein X. Normally, enzymes are active even in the presence of PP

capacity of the $S$. aureus extracellular matrix proteinbinding protein (Emp) was verified in $S$. carnosus (Hussain et al. 2001). The proof that the peptidoglycan O-acetyltransferase (OatA) causes lysozyme resistance was made in $S$. carnosus because transformation of the oatA gene into $S$. carnosus rendered the clones lysozyme resistant (Bera et al. 2006). The finding that the $S$. aureusspecific $l p l$ gene cluster triggers host cell invasion was supported by transforming the $l p l$ gene cluster into the non-invasive $S$. carnosus which became invasive after receiving the gene cluster (Nguyen et al. 2015). Also, 
S. epidermidis-derived virulence factors have been studied and verified in $S$. carnosus, such as phenol-soluble modulin peptides (Otto et al. 2004), methicillin resistance gene (Tesch et al. 1988), and biofilm formation of the S. epidermidis-derived ica genes (Heilmann et al. 1996, 2004).

\section{Development of a cloning and protein production system in $S$. carnosus}

Because of its long use in starter cultures for meat fermentation, S. carnosus is classified as a GRAS (generally recognized as safe) organism and a cloning system has therefore been developed for this species. When used as a cloning and production host, it is necessary that it can be transformed with recombinant DNA, that vectors are stably replicated, and that it has low extracellular protease activity to prevent proteolytic degradation of secreted recombinant proteins. Almost 100 S. carnosus strains were screened for transformation ability and lack of external proteolytic activity. Among those strains, S. carnosus TM300 was superior and therefore selected as a potential cloning and protein production host (Götz 1990c). Indeed, TM300 does not secrete soluble exoproteases, lipases, or hemolysins into the culture medium.

The first efforts focused on developing an efficient plasmid transformation method. Initially, the method of choice was protoplast transformation (Götz et al. 1983a), which was later improved to increase the transformation frequency (Götz and Schumacher 1987). Protoplast transformation is relatively laborious, but the reached efficiency was $10^{6}$ transformants per $\mu$ g DNA. With the advent of the less time-consuming electroporation, this method was soon applied successfully to $S$. carnosus (Augustin and Götz 1990) and was later optimized by Löfblom and coworkers (Löfblom et al. 2007a). Plasmids are widely distributed in staphylococci and some classical plasmids such as pT181, pC194, and pSX297 (Götz et al. 1983b; Horinouchi and Weisblum 1982; Novick et al. 1982) served as a basis for vector construction such as pCT20 and pCA43 (Keller et al. 1983; Kreutz and Götz 1984) or the xylose inducible and glucose repressible vectors pTX15 and pCX15 (Peschel et al. 1996; Wieland et al. 1995). In the meantime, optimized derivatives of these vectors were generated. There was also a gene replacement system developed in $S$. carnosus and $S$. xylosus that was based on temperature-sensitive Escherichia coliStaphylococcus shuttle vectors for fragment delivery and erythromycin resistance cassettes to facilitate selection of genomic copies of disrupted genes (Brückner 1997). With the development of these basic tools, a number of genes could be cloned, expressed, and analyzed for function in
S. carnosus (Brückner and Götz 1995; Götz 1990a, 1990b, 1990c).

\section{Staphylococcus hyicus lipase (SHL)-based construct for secretion of proteins}

The lipase gene (lip) from Staphylococcus hyicus subsp. hyicus was one of the first genes that was subcloned in S. carnosus (Götz et al. 1985). The lip-encoded lipase was named SHL (S. hyicus lipase) (Rosenstein and Götz 2000). SHL is the most well-characterized lipase among the staphylococcal lipases. Its activity is $\mathrm{Ca}^{2+}$-dependent, and the enzyme should rather be regarded as a phospholipase as its activity with phospholipids was higher than with triglycerides (van Oort et al. 1989). Triglycerides were fully hydrolyzed to free fatty acid and glycerol and the fatty acids of phosphatidylcholines and lysophospholipids were also completely hydrolyzed. Thus, SHL is unique among staphylococcal lipases as it has both lipase and an even higher phospholipase A1 and lysophospholipase activity. Structural analysis of the mature SHL showed that the substrate-binding cavity contains two large hydrophobic acyl chain-binding pockets and a shallow and more polar third pocket that is capable of binding either a short fatty acid or a phospholipid head group, explaining the broad substrate specificity (Tiesinga et al. 2007).

SHL turned out to be a paradigm of staphylococcal lipases as all the lipases studied so far are organized as pre-pro-lipases (Götz and Rosenstein 2001; Rosenstein and Götz 2000). The pre-sequence represents the signal peptide, which is unique as it contains a conserved YSIRK-G/S motif which appears to be involved in enhanced protein translocation or processing (Bae and Schneewind 2003; Rosenstein and Götz 2000). The 207 amino acid long propeptide (PP) is located between the signal peptide (SP) and the mature part of the lipases. Normally, the lipases are secreted in the pro-form, which is subsequently processed by an extracellular protease (Götz et al. 1998; Wenzig et al. 1990). In S. aureus, the processing enzyme is the metalloprotease aureolysin (Cadieux et al. 2014). Complete or partial deletion of the PP dramatically impaired signal peptide processing, secretion, and lipase stability, suggesting that the PP acts as an intramolecular chaperone (Demleitner and Götz 1994; Liebl and Götz 1986). The PP also protected the Escherichia coli outer membrane protein A (OmpA) from proteolytic degradation by cell-associated protease(s) in Bacillus subtilis (Meens et al. 1997).

Both the SHL-specific SP and PP were necessary to secrete heterologous proteins in large amounts (Fig. 2b). For example, the human growth hormone protein $(\mathrm{hGH})$ was efficiently produced by $S$. carnosus when fused with the PP, which can be removed from hGH by introducing an enterokinase cleavage site between PP and hGH (Sturmfels et al. 2001). In a pHauxostatic fed-batch process, the production of the human 
calcitonin (hCT) precursor fusion protein reached a concentration of $2000 \mathrm{mg} / \mathrm{L}$ within $14 \mathrm{~h}$, and after cleavage of the PP, still $420 \mathrm{mg} / \mathrm{L}$ of the recombinant hCT precursor was obtained (Dilsen et al. 2000, 2001). SHL production could be increased up to $230 \mathrm{mg} / \mathrm{mL}$ by specific fermentation techniques (Lechner et al. 1988; Märkl et al. 1990). The SHL-specific SP and PP were also successfully used to secrete large amounts of the Escherichia coli-specific alkaline phosphatase (phoA) in Bacillus subtilis; the PP protected the target protein from proteolytic degradation in the $B$. subtilis supernatant (Kouwen et al. 2010). Thus, the SHL-PP not only contributes to folding and secretion but also protects the fusion partner from proteolytic degradation. This system was also used for immobilization of enzymatically active enzymes on the cell surface of S. carnosus (Strauss and Götz 1996). These and many other examples show that the SHL secretion signals comprise a very valuable biotechnological tool for protein production/secretion in $S$. carnosus.

\section{A surface display system for $S$. carnosus}

The first use of recombinant bacteria for surface display of heterologous proteins was first reported more than two decades ago (for reviews, see (Georgiou et al. 1997; Ståhl and Uhlen 1997)) and has since attracted attention for numerous different applications in biotechnology, immunology, and applied microbiology. The first studies were mostly on Gramnegative bacteria, but approaches for surface expression on Gram-positive bacteria soon followed (Samuelson et al. 2002; Ståhl and Uhlen 1997).

In 1995, a novel expression vector for display of recombinant proteins on the surface of $S$. carnosus was described (Samuelson et al. 1995). The vector used the promoter, secretion signal, and propeptide from the Staphylococcus hyicus lipase gene in combination with the cell wall anchoring region from staphylococcal protein A ( $\mathrm{SpA})$. Between the propeptide and the anchoring part, an albumin-binding protein (ABP), derived from streptococcal protein $\mathrm{G}$, was introduced, enabling efficient monitoring of the surface expression level of individual cells using fluorescently labeled albumin as probe (Fig. 3). In fact, this allowed the quantification of the numbers of heterologously displayed proteins per staphylococcal cell using flow cytometry, and it was assessed that approximately $10^{4}$ recombinant proteins were displayed per bacterium (Andreoni et al. 1997).

Later, efforts to delete or reduce the size of the propeptide region showed that it in fact was beneficial for display of proteins that were inefficiently secreted (Samuelson et al. 1999). In a successful vector engineering effort, the vector system was further improved in terms of both plasmid size and genetic stability (Wernerus and Ståhl 2002). In addition, the vector system was later modified with a $3 \mathrm{C}$ protease substrate sequence (Fig. 3), which enabled specific proteolytic release of displayed proteins to allow detailed characterization (Kronqvist et al. 2008b).

\section{Miscellaneous early applications for surface-engineered $S$. carnosus cells}

\section{Staphylococcal biocatalysts}

Surface display is a straightforward means for production of immobilized enzymes. In a pioneering study, the lipase from Staphylococcus hyicus as well as a ß-lactamase from E. coli was displayed on $S$. carnosus, and the studies demonstrated that the enzymes retained their catalytic activity (Strauss and Götz 1996). The surface display platform was slightly different compared to the systems described above, with surfaceanchoring parts from $S$. aureus fibronectin protein B (FnBPB) instead of the SpA-derived regions. In the study, it was shown that around 10,000 enzymes were displayed on each cell, and the authors also speculated that Gram-positive staphylococci might be particularly appropriate for construction of microbial catalysts due to the rigid cell wall (Strauss and Götz 1996).

\section{Diagnostic tools}

Another interesting application for recombinant bacteria, displaying heterologous proteins on the surface, is so-called whole-cell diagnostic tools. By, for example, displaying antibody fragments or other affinity proteins on the cell, the bacteria could function as "whole-cell monoclonal antibodies" that could be used as diagnostic devises. In a first study on this concept, S. carnosus and S. xylosus were used for functional surface expression of a murine IgE-specific single-chain variable fragment ( $\mathrm{scFv}$ ) antibody fragment (Gunneriusson et al. 1996). The results from the analysis showed that the recombinant staphylococci could bind to the intended antigen and it was also the first reported display of functional antibody fragments on Gram-positive bacteria. In a follow up study, it was also demonstrated that IgE- and IgA-specific Affibody molecules (see below) could be displayed on $S$. carnosus with retained ability to bind respective antigens (Gunneriusson et al. 1999).

\section{Directed immobilization of staphylococcal cells}

Numerous reports have been published on the concept of surface-specific immobilization of bacteria for different applications, such as for whole-cell biosensors (Scouten 1995), bacterial bioadsorbents (Brower et al. 1997; Kessler 1981), and microbial biocatalysts (Freeman et al. 1996). Specific and directed immobilization of microorganisms to various matrices has the potential to be more straightforward and 
Fig. 3 Schematic representation of the expression vector for surface display of recombinant proteins on $S$. carnosus. Please note that the sizes of the different sequence elements are not in scale

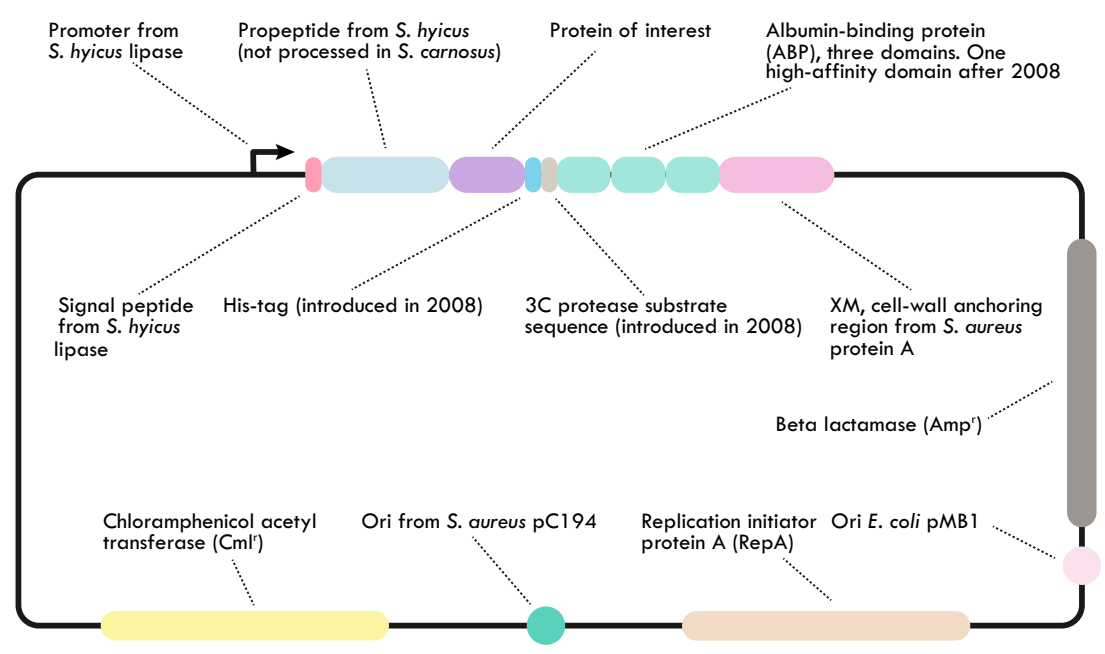

efficient when compared with conventional strategies, using for example chemical crosslinking, aggregation, or entrapment (Rehm and Omar 2008). In a pioneering study, it was demonstrated that surface expression of a fungal cellulosebinding domain (CBD) from Trichoderma reesei cellulase Cel6A on $S$. carnosus resulted in directed immobilization of the bacteria to cellulose fibers (Lehtio et al. 2001).

\section{Metal-binding staphylococci}

Toxic metals in wastewater is a growing issue worldwide and it has been suggested that recombinant bacteria that are displaying metal-binding peptides or proteins might be exploited as bioadsorbents in the bioremediation process (Brower et al. 1997). Another potential application of metalbinding bacteria is in the development of whole-cell microbial biosensors (Tibazarwa et al. 2001). Gram-positive bacteria might have an advantage in terms of bioadsorbents due to the inherent metal-binding capacity of the thick cell wall (Mullen et al. 1989). To investigate the feasibility of the concept, fusion proteins with polyhistidyl peptides for chelation of metal ions were displayed on $S$. carnosus and $S$. xylosus and the results from the study demonstrated that recombinant bacteria could adsorb metal ions as intended (Samuelson et al. 2000)

The promising results on staphylococci as recombinant bioadsorbents inspired additional studies on this application. Instead of using the polyhistidyl peptides as in the previous approach, Wernerus et al. showed that directed evolution by phage display could be used for engineering new $\mathrm{Ni}^{2+}$-binding variants of CBD (Wernerus et al. 2001). The isolated CBD variants were subsequently displayed on S. carnosus, resulting in recombinant staphylococci with $\mathrm{Ni}^{2+}$-binding capacity (Wernerus et al. 2001). The demonstrated ability to generate new specific metal-binding proteins followed by surface expression on staphylococci indicates a potential for straightforward development of inexpensive bioadsorbents for bioremediation of toxic metals in the future.

\section{S. carnosus as a live vaccine delivery system}

As mentioned above, $S$. carnosus is a GRAS (generally regarded as safe) organism and has been used extensively in the food industry for decades, which makes it a potentially suitable strain in the vaccine field for oral delivery of recombinant immunogens. In an initial effort, administrations of high doses of $S$. carnosus to mice by mucosal or subcutaneous routes were shown to be safe and well tolerated (Ståhl et al. 1997). Recombinant S. carnosus (Samuelson et al. 1995) and S. xylosus (Hansson et al. 1992), displaying ABP as a model immunogen, were also used in a comparative immunization study, demonstrating that the $S$. carnosus system was superior compared with S. xylosus for oral immunization (Robert et al. 1996; Ståhl et al. 1997). Although the reasons behind these results are not completely clear, the authors speculated that it might be due to the higher surface expression level on S. carnosus (Andreoni et al. 1997; Robert et al. 1996).

Although the initial vaccine studies with recombinant staphylococci demonstrated systemic antibody responses, the obtained antibody titers were relatively modest (Liljeqvist and Ståhl 1999). Later investigations were thus focused on strategies for increasing the antibody response to the surfacedisplayed antigens (Cano et al. 1999; Liljeqvist et al. 1997). The second-generation whole-cell vaccine delivery vehicles were hence modified by fusing the model immunogen to another recombinant protein with adhesive properties, in order to achieve targeting of the bacterial vaccine vehicles to the mucosal epithelium. Three different adhesion proteins were investigated in the study: (i) a fibronectin binding domain from Streptococcus dysgalactiae (Liljeqvist et al. 1999), (ii) a cholera toxin B (CTB)-derived peptide, CTBp (Cano et al. 1999), and (iii) a bacterial adhesion factor. The results demonstrated 
that co-display of any of the evaluated adhesion proteins on the surface of $S$. carnosus yielded elevated serum antibody responses to the displayed immunogen after intranasal administration into mice (Liljeqvist and Ståhl 1999). The encouraging results resulted in a follow-up study, where CTBp was fused to an antigen from the $G$ glycoprotein of human respiratory syncytial virus (RSV) and displayed on $S$. carnosus (Cano et al. 2000). The recombinant staphylococci were thereafter used for intranasal immunization of mice, which elicited a significant anti-RSV serum IgG response. Moreover, lung protection was shown for around $50 \%$ of the animals after viral challenge with 100,000 tissue culture infectious doses 50 $\left(\mathrm{TCID}_{50}\right)$ and was thus the first reported study that could demonstrate protective immunity to a virus using vaccination with recombinant food-grade bacteria (Cano et al. 2000).

\section{Peptide and protein libraries displayed on $S$. carnosus.}

Surface display of recombinant protein and peptide libraries on cells is an attractive complement to the conventional phage display technology. Yeast display of antibody libraries (Cherf and Cochran 2015) is the most established approach, but similar methods have also been developed based on bacteria (Löfblom 2011). The main reason for using cells over phages is the option to use fluorescence-activated cell sorting (FACS) for screening the libraries and for isolation of desired clones (Fig. 4a). The multivalent display of recombinant proteins on the surface $(>10,000$ per cell) yields a quantitative fluorescent signal in the flow cytometer that corresponds to the relative affinity, resulting in efficient selection of high affinity variants. Flow-cytometric sorting also provides a direct visualization of the enrichment procedure of binders throughout each selection round in the process.

\section{Combinatorial protein engineering of affinity proteins using staphylococcal display and FACS}

The first study showing the potential of $S$. carnosus for combinatorial protein engineering was published in 2003 and demonstrated that recombinant Affibody molecules (Löfblom et al. 2010; Nord et al. 1997; Ståhl et al. 2017) displayed on the bacterial surface could be enriched by FACS from a large background $(1: 100,000)$ of non-binders (Wernerus et al. 2003).

One of the characteristics of cell display of combinatorial libraries combined with FACS is the ability to discriminate between variants with relatively small differences in affinity, facilitating isolation of the strongest binders during selection. In a study from 2005 , a mock sorting was conducted to explore the discrimination capacity of the staphylococcal method (Löfblom et al. 2005). The albumin-binding fusion protein was employed as a surface expression monitoring tag and cells were labeled with a saturating concentration of fluorescently labeled albumin (Fig. 4b). By normalizing the target-binding signal with the surface-expressing level, the distribution in signal was reduced dramatically. It was furthermore demonstrated that flow-cytometric sorting from a mock library on $S$. carnosus that contained binders with twofold higher affinity mixed 1:1000 in a background of a weaker variant resulted in efficient isolation from a single round with an enrichment factor of around 140-fold.

Another feature of cell display is that isolated individual variants after sorting can be characterized directly on the cell surface using flow cytometry, obviating initial subcloning for soluble protein production of candidates. Using the staphylococcal display platform, it was demonstrated that both the equilibrium dissociation constant and the dissociation rate constant could be accurately determined in the flow cytometer (Löfblom et al. 2007b). Moreover, in a following publication, it was shown that the recombinant protein could be released from the surface by specific proteolytic cleavage and that the obtained soluble binders were functional in different assays (Kronqvist et al. 2008b).

Although the studies described so far had shown the potential of $S$. carnosus for library applications, the most critical challenge still remained-transformation of the DNAencoded library to the staphylococcal host. While the relatively thick peptidoglycan cell wall is a favorable feature in FACS as the viability of isolated clones is nearly unaffected by the harsh sorting conditions, it also limits the transformation frequency. Library complexity and the probability of finding high-affinity variants are directly correlated, which means that transforming millions of clones is basically a requirement for success in combinatorial protein engineering. In an effort to increase the relatively modest transformation frequency of S. carnosus, a number of different parameters for electroporation were optimized, including the addition of a heat-treatment step to temporarily knock out the host restriction enzymes, enabling transformation of high concentrations of plasmid DNA prepared in E. coli (Löfblom et al. 2007a). Overall, the optimization resulted in 10,000-fold higher transformation frequency, corresponding to around $10^{6}$ transformed staphylococci per electroporation event.

The improved transformation frequency opened up the possibility to construct large libraries on $S$. carnosus. In a pioneering study, a pre-selected Affibody library from phage display was transferred to staphylococci and subnanomolar binders for tumor necrosis factor (TNF) alpha; TNF alpha were efficiently isolated using FACS (Kronqvist et al. 2008a). Following the first reported staphylococcal library, the method has since been used extensively for affinity maturation of Affibody molecules. Examples include affinity maturation of a human epidermal growth factor receptor 3 (HER3)-specific Affibody down to around 20 pM affinity 
a

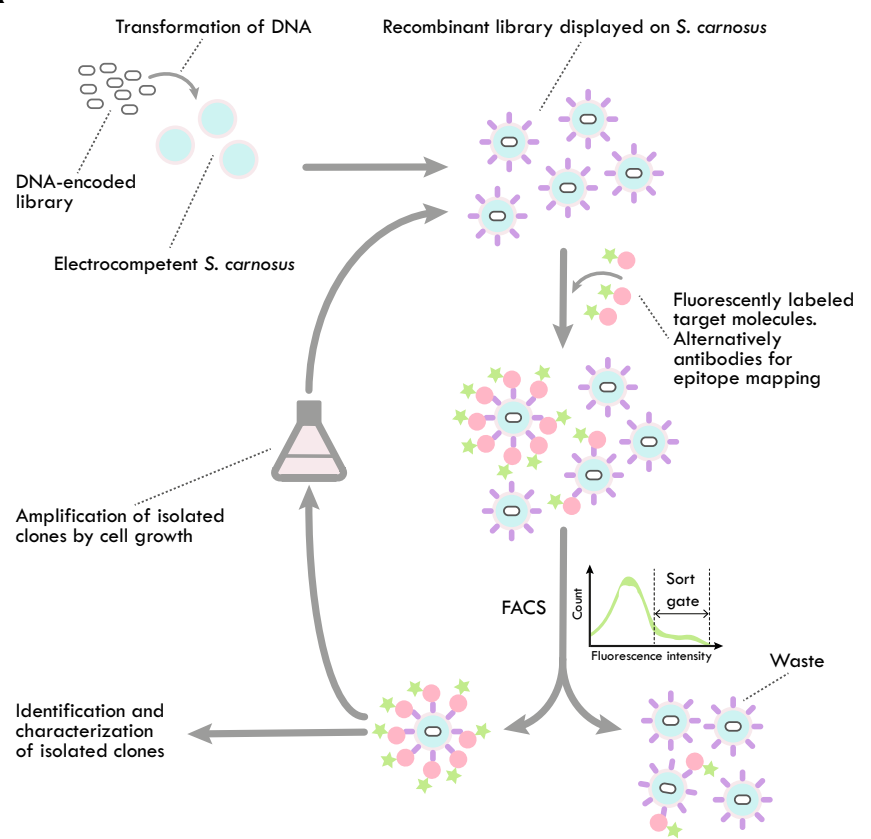

b



Fig. 4 FACS of S. carnosus displaying recombinant protein or peptide libraries. a Schematic representation of staphylococcal surface display and FACS. Staphylococcal surface expression vectors, encoding protein, or peptide libraries are transformed to $S$. carnosus using electroporation. After expression on the bacterial surface, the combinatorial libraries on staphylococci are incubated with fluorescently labeled target (or antibodies for epitope mapping) and subsequently sorted for isolation of binding variants using FACS. The sorting is typically repeated for several rounds with amplification by growth in between cycles until required enrichment is reached. After sorting, the isolated recombinant proteins or peptides are identified using DNA sequencing. For epitope mapping, the sequence information is used to determine the epitope. For directed evolution of affinity proteins, the affinity as well as the specificity is thereafter determined directly on the cell surface using flow cytometry, followed by subcloning and production of soluble proteins. b Schematic representation of the recombinant fusion protein displayed on the surface of $S$. carnosus for library applications and FACS. Cells are incubated with fluorescently labeled target protein (or antibodies for epitope mapping) as well as with fluorescently labeled albumin for monitoring of the surface expression level and normalization during FACS. Please note that approximately 10,000 copies of recombinant protein are displayed per cell, resulting in a quantitative signal in the flow cytometer, corresponding to the affinity for the target
(Kronqvist et al. 2011; Malm et al. 2013), affinity maturation of a head-to-tail dimeric Affibody for the amyloid beta peptide to 300 pM affinity (Lindberg et al. 2013, 2015), and more recently, affinity maturation of two distinct Affibody molecules for vascular endothelial growth factor receptor 2 (VEGFR2) (Fleetwood et al. 2014), which were later formatted as a so-called biparatopic binder with extremely slow dissociation from the receptor (Fleetwood et al. 2016).

In addition to combinatorial engineering of Affibody molecules, the method has also been used for isolation of other types of affinity proteins. One example is engineering of socalled ADAPT molecules (ABD-derived affinity protein), which are based on an albumin-binding domain from streptococcal protein G (Alm et al. 2010). For the ADAPTs, the libraries were designed with the intention of preserving the affinity for albumin, while engineering an additional specific binding on the opposite surface of the affinity protein. In these efforts, the possibility to use multiparameter FACS was exploited and albumin and target were labeled with different fluorophores, enabling efficient engineering of bispecific binders by monitoring both signals simultaneously in the flow cytometer. Bispecific ADAPTs for TNF (Nilvebrant et al. 2011), human epidermal growth factor receptor 2 (HER2) (Nilvebrant et al. 2014), and HER3 (Åstrand 2016), respectively, have been successfully isolated using that approach from libraries displayed on staphylococci.

Staphylococcal display has also been used for selection of specific antibody fragments. Fleetwood and coworkers subcloned an immune so-called nanobody (i.e., singledomain VHH from camelid heavy-chain-only antibodies) library to the staphylococcal display vector and used FACS for isolation of green fluorescent protein (GFP)-specific camelid antibodies (Fleetwood et al. 2013). The same library had previously been used for selecting nanobodies to GFP using phage display and when comparing the output from the two methods, it was demonstrated that the staphylococcal method yielded binders with a higher affinity on average and that the clones were relatively different between the two methods. Another more recent example is a study where $S$. carnosus was used for engineering of HER2-specific single-chain variable fragment $(\mathrm{scFv})$ antibodies (personal communication Johan Rockberg, KTH). Staphylococcal display and FACS 
was used both for selection of first-generation binders as well as for affinity maturation with an error-prone PCR-generated library to yield human scFvs in the low nanomolar range.

\section{Display of peptide libraries on $\boldsymbol{S}$. carnosus for profiling of protease substrates}

In addition to the generation of specific affinity proteins, the staphylococcal platform has been evaluated for display of peptide libraries for various purposes. One recent publication describes how the method can be utilized for substrate profiling of proteases as well as for discovery of new improved substrates that are processed with higher catalytic activity. The method is based on display of random peptide substrate libraries on the surface of staphylococci followed by addition of protease and subsequent FACS for isolation and identification of cleaved substrates. In the method, an Affibody is expressed on the surface as a reporter tag. In-fusion with the reporter tag is another domain that specifically blocks the reporter tag from binding a soluble fluorescently labeled reporter (Sandersjoo et al. 2015). The linker between the two domains contains a substrate peptide library. Upon addition of protease, variants with a functional substrate will be cleaved within the linker, resulting in release of the blocking domain and binding of the fluorescent reporter molecule. Using substrate libraries for tobacco etch virus (TEV) protease and matrix metalloprotease (MMP)-1, the substrate profiles for the respective protease were identified and several new peptides were isolated for MMP-1 that were processed with up to eightfold higher catalytic activity compared with previously reported substrates (Sandersjoo et al. 2017).

\section{Display of peptide and protein libraries on $S$. carnosus for epitope mapping}

Several studies have also reported on the use of the staphylococcal display method for epitope mapping of antibodies. Two approaches have so far been explored for this purpose. The first is based on surface display of antigenderived peptide libraries, differing in length and covering the entire sequence of the antigen. By incubating the peptide libraries with fluorescently labeled antibodies and subsequent FACS (Fig. 4), the corresponding epitopes for both monoclonal and polyclonal antibodies binding to a panel of different antigens have been identified (Hjelm et al. 2010, 2012; Kronqvist et al. 2010; Rockberg et al. 2008, 2010). In a more large-scale approach, Hudson and colleagues created a peptide library covering the sequences of 60 clinically relevant protein targets (Hudson et al. 2012). The library was used to map the epitopes of several different antibodies and sequencing the output revealed off-target binding in some cases, demonstrating that the strategy is also powerful for investigating potential cross-reactivity. Although the lengths of the peptides in the library can be adjusted and it has been shown that conformational epitopes might be identified for certain antigen/antibody pairs, in general, the antigen-derived peptide libraries are more suitable for discovery of linear epitopes. Another complementary approach is to express full-length proteins or independently folded domains and construct error-prone PCR libraries on staphylococci followed by sorting for loss of binding. This strategy was used for mapping the conformational epitope of the monoclonal antibody eculizumab, which is used in the clinics for treating patients with paroxysmal nocturnal hemoglobinuria (PNH) and atypical hemolytic uremic syndrome (aHUS) (Volk et al. 2016). Interestingly, the identified epitope explained the previously observed non-responsiveness to treatment in a subpopulation of patients of Japanese origin, carrying a mutation in the epitope.

\section{Conclusions and future perspectives}

S. carnosus is a non-pathogenic Gram-positive staphylococcal species. It has for a long time (and is still today) been used as part of starter cultures for meat fermentation and in other food processes. An essential function of $S$. carnosus in starter cultures is to prevent the growth of undesirable bacteria, thus reducing the risk of food poisoning and acting as a food preservative. Importantly, S. carnosus also contributes favorably to development of flavor and red color as well as to decreasing $\mathrm{pH}$ and hydrogen peroxide. Due to the many valuable and often unique properties of $S$. carnosus, it will most likely continue to play an important role in food processing in the future. In 2009, the genome sequence of $S$. carnosus was published, which verified and explained its previously reported non-pathogenic behavior. S. carnosus lacks important virulence factors found in many pathogenic bacteria. This has made $S$. carnosus a very valuable scientific model organism for studying and elucidating the mechanism of isolated genes from, for example, S. aureus for pathogenicity. As staphylococcal infections and the general issue of increasing antibiotic resistance is continuing to grow globally, we expect that S. carnosus will be an even more important tool for such studies in the future, as part of the large efforts to combat these, sometimes deadly, infectious diseases. Due to the long historic use in the food industry and the now verified nonpathogenic properties, S. carnosus is classified as a GRAS organism. Moreover, the straightforward translocation of recombinant proteins over the single-cell membrane in Grampositive bacteria combined with the very low proteolytic extracellular activity makes $S$. carnosus an attractive host for production of secreted recombinant proteins. Methods for transformation, subcloning, and protein production in 
S. carnosus are established today and yields of grams per liter culture for recombinant human proteins have been reported. Although the post-translational modifications of human proteins are different compared to eukaryotic hosts, S. carnosus has the potential to become an attractive complementary prokaryotic production host in cases when such modifications are not critical for the intended application.

In addition to secreted production of soluble recombinant proteins, a vector system has also been developed for surface display of recombinant proteins and peptides on the surface of S. carnosus. It has been used for a number of different applications, such as display of metal-binding peptides with the long-term goal of using them as whole-cell bioadsorbents for purification of metal pollutants from wastewater. Another example is a whole-cell biocatalyst where enzymes are displayed on the bacteria, obviating the need for production and purification of soluble enzymes. Since $S$. carnosus is a GRAS organism and not pathogenic, it has also been investigated relatively extensively as a vaccine delivery vehicle, carrying antigenic determinants displayed on the surface, in several preclinical vaccination studies with encouraging results. More recently, optimization of the DNA transformation efficiency has enabled expression of large libraries of recombinant proteins or peptides on $S$. carnosus. Screening such libraries with FACS has been used for directed evolution of a range of different affinity proteins, substrate profiling of proteases, as well as for epitope mapping of antibodies. With the successful results from these different library applications, we expect that $S$. carnosus will be a valuable complement to phage and yeast display in the years to come.

In summary, $S$. carnosus will definitely continue to be an important microorganism in a very broad range of applications in the future, all the way from being part of starter cultures in sausage fermentation to host in powerful methods for directed evolution of new biopharmaceuticals.

Acknowledgements A majority of the reviewed research performed at KTH (SS, JL) have been funded by grants from the Swedish Research Council and the Deutsche Forschungsgemeinschaft DFG (FG).

\section{Compliance with ethical standards}

Conflict of interest The authors declare that they have no conflict of interest.

Ethical approval This article does not contain any studies with human participants or animals performed by any of the authors.

Open Access This article is distributed under the terms of the Creative Commons Attribution 4.0 International License (http:// creativecommons.org/licenses/by/4.0/), which permits unrestricted use, distribution, and reproduction in any medium, provided you give appropriate credit to the original author(s) and the source, provide a link to the Creative Commons license, and indicate if changes were made.

\section{References}

Agerer F, Lux S, Michel A, Rohde M, Ohlsen K, Hauck CR (2005) Cellular invasion by Staphylococcus aureus reveals a functional link between focal adhesion kinase and cortactin in integrin-mediated internalisation. J Cell Sci 118(Pt 10):2189-2200

Alm T, Yderland L, Nilvebrant J, Halldin A, Hober S (2010) A small bispecific protein selected for orthogonal affinity purification. Biotechnol J 5(6):605-617. https://doi.org/10.1002/biot.201000041

Andreoni C, Goetsch L, Libon C, Samuelson P, Nguyen TN, Robert A, Uhlen M, Binz H, Ståhl S (1997) Flow cytometric quantification of surface-displayed recombinant receptors on staphylococci. BioTechniques 23(4):696-702 704

Åstrand M, Nilvebrant J, Björnmalm M, Lindbo S, Hober S, Löfblom J (2016) Investigating affinity-maturation strategies and reproducibility of fluorescence-activated cell sorting using a recombinant ADAPT library displayed on staphylococci. Protein Eng Des Sel 29(5):187-195

Augustin J, Götz F (1990) Transformation of Staphylococcus epidermidis and other staphylococcal species with plasmid DNA by electroporation. FEMS Microbiol Lett 54(1-3):203-207

Bae T, Schneewind O (2003) The YSIRK-G/S motif of staphylococcal protein $\mathrm{A}$ and its role in efficiency of signal peptide processing. $\mathrm{J}$ Bacteriol 185(9):2910-2919

Barriere C, Leroy-Setrin TR (2001) Characterization of catalase and superoxide dismutase in Staphylococcus carnosus 833 strain. J Appl Microbiol 91:514-519

Bera A, Herbert S, Jakob A, Vollmer W, Götz F (2005) Why are pathogenic staphylococci so lysozyme resistant? The peptidoglycan Oacetyltransferase OatA is the major determinant for lysozyme resistance of Staphylococcus aureus. Mol Microbiol 55(3):778-787

Bera A, Biswas R, Herbert S, Götz F (2006) The presence of peptidoglycan O-acetyltransferase in various staphylococcal species correlates with lysozyme resistance and pathogenicity. Infect Immun 74(8):4598-4604

Brower JB, Ryan RL, Pazirandeh M (1997) Comparison of ion-exchange resins and biosorbents for the removal of heavy metals from plating factory wastewater. Environ Sci Technol 31(10):2910-2914. https:// doi.org/10.1021/es970104i

Brückner R (1997) Gene replacement in Staphylococcus carnosus and Staphylococcus xylosus. FEMS Microbiol Lett 151(1):1-8

Brückner R, Götz F (1995) Development of a food-grade vector system for Staphylococcus carnosus. System Appl Microbiol 18:510-516

Cadieux B, Vijayakumaran V, Bernards MA, McGavin MJ, Heinrichs DE (2014) Role of lipase from community-associated methicillin-resistant Staphylococcus aureus strain USA300 in hydrolyzing triglycerides into growth-inhibitory free fatty acids. J Bacteriol 196(23): 4044-4056. https://doi.org/10.1128/JB.02044-14

Cano F, Liljeqvist S, Nguyen TN, Samuelson P, Bonnefoy JY, Ståhl S, Robert A (1999) A surface-displayed cholera toxin B peptide improves antibody responses using food-grade staphylococci for mucosal subunit vaccine delivery. FEMS Immunol Med Microbiol 25(3):289-298

Cano F, Plotnicky-Gilquin H, Nguyen TN, Liljeqvist S, Samuelson P, Bonnefoy J, Ståhl S, Robert A (2000) Partial protection to respiratory syncytial virus (RSV) elicited in mice by intranasal immunization using live staphylococci with surface-displayed RSV-peptides. Vaccine 18(24):2743-2752

Castric PA (1975) Hydrogen cyanide, a secondary metabolite of Pseudomonas aeruginosa. Can J Microbiol 21(5):613-618

Cherf GM, Cochran JR (2015) Applications of yeast surface display for protein engineering. Methods Mol Biol 1319:155-175. https://doi. org/10.1007/978-1-4939-2748-7_8

Corbiere Morot-Bzot S, Leroy S, Talon R (2007) Monitoring of staphylococcal starters in two French processing plants manufacturing dry fermented sausages. J Appl Microbiol 102:238-244 
Cotter PA, Melville SB, Albrecht JA, Gunsalus RP (1997) Aerobic regulation of cytochrome $\mathrm{d}$ oxidase $(c y d A B)$ operon expression in Escherichia coli: roles of Fnr and ArcA in repression and activation. Mol Microbiol 25(3):605-615

Demleitner G, Götz F (1994) Evidence for importance of the Staphylococcus hyicus lipase pro-peptide in lipase secretion, stability and activity. FEMS Microbiol Lett 121:189-197

Dilsen S, Paul W, Sandgathe A, Tippe D, Freudl R, Thommes J, Kula MR, Takors R, Wandrey C, Weuster-Botz D (2000) Fed-batch production of recombinant human calcitonin precursor fusion protein using Staphylococcus carnosus as an expression-secretion system. Appl Microbiol Biotechnol 54(3):361-369

Dilsen S, Paul W, Herforth D, Sandgathe A, Altenbach-Rehm J, Freudl R, Wandrey C, Weuster-Botz D (2001) Evaluation of parallel operated small-scale bubble columns for microbial process development using Staphylococcus carnosus. J Biotechnol 88(1):77-84

Fast B, Lindgren P, Götz F (1996) Cloning, sequencing, and characterization of a gene (narT) encoding a transport protein involved in dissimilatory nitrate reduction in Staphylococcus carnosus. Arch Microbiol 166(6):361-367

Fedtke I, Kamps A, Krismer B, Götz F (2002) The nitrate reductase and nitrite reductase operons and the narT gene of Staphylococcus carnosus are positively controlled by the novel two-component system NreBC. J Bacteriol 184:6624-6634

Fleetwood F, Devoogdt N, Pellis M, Wernery U, Muyldermans S, Ståhl S, Löfblom J (2013) Surface display of a single-domain antibody library on Gram-positive bacteria. Cell Mol Life Sci 70(6):10811093. https://doi.org/10.1007/s00018-012-1179-y

Fleetwood F, Klint S, Hanze M, Gunneriusson E, Frejd FY, Ståhl S, Löfblom J (2014) Simultaneous targeting of two ligand-binding sites on VEGFR2 using biparatopic Affibody molecules results in dramatically improved affinity. Sci Rep 4:7518. https://doi.org/10. 1038/srep07518

Fleetwood F, Guler R, Gordon E, Ståhl S, Claesson-Welsh L, Löfblom J (2016) Novel affinity binders for neutralization of vascular endothelial growth factor (VEGF) signaling. Cell Mol Life Sci 73(8):16711683. https://doi.org/10.1007/s00018-015-2088-7

Freeman A, Abramov S, Georgiou G (1996) Fixation and stabilization of Escherichia coli cells displaying genetically engineered cell surface proteins. Biotechnol Bioeng 52(5):625-630. https://doi.org/10.1002/(SICI) 1097-0290(19961205)52:5<625::AID-BIT10>3.0.CO;2-E

Georgiou G, Stathopoulos C, Daugherty PS, Nayak AR, Iverson BL, Curtiss R 3rd (1997) Display of heterologous proteins on the surface of microorganisms: from the screening of combinatorial libraries to live recombinant vaccines. Nat Biotechnol 15(1):29-34. https://doi. org/10.1038/nbt0197-29

Götz F (1990a) Applied genetics in the Gram positive bacterium Staphylococcus carnosus. Food Biotechnol 4:505-513

Götz F (1990b) Development of a cloning system in Staphylococcus carnosus: different processing of the Staphylococcus hyicus lipase in Staphylococcus carnosus and Staphylococcus hyicus. In: Novick RP (ed) Molecular biology of the staphylococci. VCH Publishers, New York, pp 273-281

Götz F (1990c) Staphylococcus carnosus: a new host organism for gene cloning and protein production. Soc Appl Bacteriol Symp Ser 19: 49S-53S

Götz F, Rosenstein R (2001) Staphylococcal lipases: molecular characterization and use as an expression and secretion system. In: Braun V, Götz F (eds) Microbial fundamentals of biotechnology. WILEYVCH Verlag GmbH, Weinheim, pp 238-248

Götz F, Schumacher B (1987) Improvements of protoplast transformation in Staphylococcus carnosus. FEMS Microbiol Lett 40:285-288

Götz F, Kreuz B, Schleifer KH (1983a) Protoplast transfomation of Staphylococcus carnosus by plasmid DNA. Mol Gen Genet 189: 340-342
Götz F, Zabielski J, Philipson L, Lindberg M (1983b) DNA homology between the arsenate resistance plasmid pSX267 from Staphylococcus xylosus and the penicillinase plasmid pI258 from Staphylococcus aureus. Plasmid 9(2):126-137

Götz F, Popp F, Korn E, Schleifer KH (1985) Complete nucleotide sequence of the lipase gene from Staphylococcus hyicus cloned in Staphylococcus carnosus. Nucleic Acids Res 13:5895-5906

Götz F, Verheij HM, Rosenstein R (1998) Staphylococcal lipases: molecular characterisation, secretion, and processing. Chem Phys Lipids 93(1-2):15-25

Götz F, Bannerman T, Schleifer KH (2006) The genera Staphylococcus and Macrococcus. In: Dworkin M (ed) Procaryotes, vol 4. Springer, New York, pp 5-75

Grundmeier M, Hussain M, Becker P, Heilmann C, Peters G, Sinha B (2004) Truncation of fibronectin-binding proteins in Staphylococcus aureus strain Newman leads to deficient adherence and host cell invasion due to loss of the cell wall anchor function. Infect Immun 72(12):7155-7163

Gunneriusson E, Samuelson P, Uhlen M, Nygren PA, Ståhl S (1996) Surface display of a functional single-chain Fv antibody on staphylococci. J Bacteriol 178(5):1341-1346

Gunneriusson E, Samuelson P, Ringdahl J, Gronlund H, Nygren PA, Ståhl S (1999) Staphylococcal surface display of immunoglobulin A (IgA)- and IgE-specific in vitro-selected binding proteins (affibodies) based on Staphylococcus aureus protein A. Appl Environ Microbiol 65(9):4134-4140

Haggar A, Hussain M, Lonnies H, Herrmann M, Norrby-Teglund A, Flock JI (2003) Extracellular adherence protein from Staphylococcus aureus enhances internalization into eukaryotic cells. Infect Immun 71(5):2310-2317

Hammes WP (2012) Metabolism of nitrate in fermented meats: the characteristic feature of a specific group of fermented foods. Food Microbiol 29(2):151-156. https://doi.org/10.1016/j.fm.2011.06.016

Hansson M, Ståhl S, Nguyen TN, Bachi T, Robert A, Binz H, Sjolander A, Uhlen M (1992) Expression of recombinant proteins on the surface of the coagulase-negative bacterium Staphylococcus xylosus. J Bacteriol 174(13):4239-4245

Hassan HM, Fridovich I (1980) Mechanism of the antibiotic action pyocyanine. J Bacteriol 141(1):156-163

Heilmann C, Gerke C, Perdreau-Remington F, Götz F (1996) Characterization of Tn917 insertion mutants of Staphylococcus epidermidis affected in biofilm formation. Infect Immun 64(1):277-282

Heilmann C, Niemann S, Sinha B, Herrmann M, Kehrel BE, Peters G (2004) Staphylococcus aureus fibronectin-binding protein (FnBP)mediated adherence to platelets, and aggregation of platelets induced by FnBPA but not by FnBPB. J Infect Dis 190(2):321-329

Hjelm B, Fernandez CD, Löfblom J, Ståhl S, Johannesson H, Rockberg J, Uhlen M (2010) Exploring epitopes of antibodies toward the human tryptophanyl-tRNA synthetase. New Biotechnol 27(2):129-137. https://doi.org/10.1016/j.nbt.2009.11.001

Hjelm B, Forsstrom B, Löfblom J, Rockberg J, Uhlen M (2012) Parallel immunizations of rabbits using the same antigen yield antibodies with similar, but not identical, epitopes. PLoS One 7(12):e45817. https://doi.org/10.1371/journal.pone.0045817

Horinouchi S, Weisblum B (1982) Nucleotide sequence and functional map of pC194, a plasmid that specifies inducible chloramphenicol resistance. J Bacteriol 150(2):815-825

Hudson EP, Uhlen M, Rockberg J (2012) Multiplex epitope mapping using bacterial surface display reveals both linear and conformational epitopes. Sci Rep 2:706. https://doi.org/10.1038/srep00706

Hussain M, Becker K, von Eiff C, Schrenzel J, Peters G, Herrmann M (2001) Identification and characterization of a novel 38.5-kilodalton cell surface protein of Staphylococcus aureus with extendedspectrum binding activity for extracellular matrix and plasma proteins. J Bacteriol 183(23):6778-6786 
Kamps A, Achebach S, Fedtke I, Unden G, Götz F (2004) Staphylococcal $\mathrm{NreB}$ : an O-sensing histidine protein kinase with an O-labile ironsulphur cluster of the FNR type. Mol Microbiol 52(3):713-723

Keller G, Schleifer KH, Götz F (1983) Construction and characterization of plasmid vectors for cloning in Staphylococcus aureus and Staphylococcus carnosus. Plasmid 10(3):270-278

Kerdudou S, Laschke MW, Sinha B, Preissner KT, Menger MD, Herrmann M (2006) Fibronectin binding proteins contribute to the adherence of Staphylococcus aureus to intact endothelium in vivo. Thromb Haemost 96(2):183-189

Kessler SW (1981) Use of protein A-bearing staphylococci for the immunoprecipitation and isolation of antigens from cells. Methods Enzymol 73(Pt B):442-459

Kouwen TR, Nielsen AK, Denham EL, Dubois JY, Dorenbos R, Rasmussen MD, Quax WJ, Freudl R, van Dijl JM (2010) Contributions of the pre- and pro-regions of a Staphylococcus hyicus lipase to secretion of a heterologous protein by Bacillus subtilis. Appl Environ Microbiol 76(3):659-669. https://doi.org/10.1128/ AEM.01671-09

Kreutz B, Götz F (1984) Construction of Staphylococcus plasmid vector pCA43 conferring resistance to chloramphenicol, arsenate, arsenite and antimony. Gene 31(1-3):301-304

Kronqvist N, Löfblom J, Jonsson A, Wernerus H, Ståhl S (2008a) A novel affinity protein selection system based on staphylococcal cell surface display and flow cytometry. Protein Eng Des Sel 21(4):247255. https://doi.org/10.1093/protein/gzm090

Kronqvist N, Löfblom J, Severa D, Ståhl S, Wernerus H (2008b) Simplified characterization through site-specific protease-mediated release of affinity proteins selected by staphylococcal display. FEMS Microbiol Lett 278(1):128-136. https://doi.org/10.1111/j. 1574-6968.2007.00990.x

Kronqvist N, Malm M, Rockberg J, Hjelm B, Uhlen M, Ståhl S, Löfblom J (2010) Staphylococcal surface display in combinatorial protein engineering and epitope mapping of antibodies. Recent Pat Biotechnol 4(3):171-182

Kronqvist N, Malm M, Gostring L, Gunneriusson E, Nilsson M, Hoiden Guthenberg I, Gedda L, Frejd FY, Ståhl S, Löfblom J (2011) Combining phage and staphylococcal surface display for generation of ErbB3-specific Affibody molecules. Protein Eng Des Sel 24(4): 385-396. https://doi.org/10.1093/protein/gzq118

Lechner M, Märkl H, Götz F (1988) Lipase production of Staphylococcus carnosus in a dialysis fermentor. Appl Microbiol Biotechnol 28: 345-349

Lehtio J, Wernerus H, Samuelson P, Teeri TT, Ståhl S (2001) Directed immobilization of recombinant staphylococci on cotton fibers by functional display of a fungal cellulose-binding domain. FEMS Microbiol Lett 195(2):197-204

Lerche M, Sinell HJ (1955) Zum Vorkommen von Kokken in Rohwürsten. Arch Leb 6:194-198

Liebl W, Götz F (1986) Studies on lipase directed export of Escherichia coli beta-lactamase in Staphylococcus carnosus. Mol Gen Genet 204(1):166-173

Liepe H-U, Porobic R (1983) Influence of storage conditions on survival rates and fermentative activity of lyophilized staphylococci. Fleischwirtschaft 63:1756-1757

Liljeqvist S, Ståhl S (1999) Production of recombinant subunit vaccines: protein immunogens, live delivery systems and nucleic acid vaccines. J Biotechnol 73(1):1-33

Liljeqvist S, Samuelson P, Hansson M, Nguyen TN, Binz H, Ståhl S (1997) Surface display of the cholera toxin B subunit on Staphylococcus xylosus and Staphylococcus carnosus. Appl Environ Microbiol 63(7):2481-2488

Liljeqvist S, Cano F, Nguyen TN, Uhlen M, Robert A, Ståhl S (1999) Surface display of functional fibronectin-binding domains on Staphylococcus carnosus. FEBS Lett 446(2-3):299-304
Lindberg H, Johansson A, Hard T, Ståhl S, Löfblom J (2013) Staphylococcal display for combinatorial protein engineering of a head-to-tail affibody dimer binding the Alzheimer amyloid-beta peptide. Biotechnol J 8(1):139-145. https://doi.org/10.1002/biot. 201200228

Lindberg H, Hard T, Löfblom J, Ståhl S (2015) A truncated and dimeric format of an Affibody library on bacteria enables FACS-mediated isolation of amyloid-beta aggregation inhibitors with subnanomolar affinity. Biotechnol J 10(11):1707-1718. https://doi.org/10.1002/ biot.201500131

Löfblom J (2011) Bacterial display in combinatorial protein engineering. Biotechnol J 6(9):1115-1129. https://doi.org/10.1002/biot. 201100129

Löfblom J, Wernerus H, Ståhl S (2005) Fine affinity discrimination by normalized fluorescence activated cell sorting in staphylococcal surface display. FEMS Microbiol Lett 248(2):189-198. https://doi.org/ 10.1016/j.femsle.2005.05.040

Löfblom J, Kronqvist N, Uhlen M, Ståhl S, Wernerus H (2007a) Optimization of electroporation-mediated transformation: Staphylococcus carnosus as model organism. J Appl Microbiol 102(3):736-747. https://doi.org/10.1111/j.1365-2672.2006.03127.x

Löfblom J, Sandberg J, Wernerus H, Ståhl S (2007b) Evaluation of staphylococcal cell surface display and flow cytometry for postselectional characterization of affinity proteins in combinatorial protein engineering applications. Appl Environ Microbiol 73(21):6714-6721. https://doi.org/10.1128/AEM.01432-07

Löfblom J, Feldwisch J, Tolmachev V, Carlsson J, Ståhl S, Frejd FY (2010) Affibody molecules: engineered proteins for therapeutic, diagnostic and biotechnological applications. FEBS Lett 584(12): 2670-2680. https://doi.org/10.1016/j.febslet.2010.04.014

Machan ZA, Taylor GW, Pitt TL, Cole PJ, Wilson R (1992) 2-Heptyl-4hydroxyquinoline $\mathrm{N}$-oxide, an antistaphylococcal agent produced by Pseudomonas aeruginosa. J Antimicrob Chemother 30(5):615623

Malm M, Kronqvist N, Lindberg H, Gudmundsdotter L, Bass T, Frejd FY, Hoiden-Guthenberg I, Varasteh Z, Orlova A, Tolmachev V, Ståhl S, Löfblom J (2013) Inhibiting HER3-mediated tumor cell growth with affibody molecules engineered to low picomolar affinity by position-directed error-prone PCR-like diversification. PLoS One 8(5):e62791. https://doi.org/10.1371/journal.pone.0062791

Märkl H, Lechner M, Götz F (1990) A new dialysis fermentor for the production of high concentrations of extracellular enzymes. J Ferment Bioeng 69:244-249

Meens J, Herbort M, Klein M, Freudl R (1997) Use of the pre-pro part of Staphylococcus hyicus lipase as a carrier for secretion of Escherichia coli outer membrane protein A (OmpA) prevents proteolytic degradation of OmpA by cell-associated protease(s) in two different gram-positive bacteria. Appl Environ Microbiol 63(7):2814-2820

Mullen MD, Wolf DC, Ferris FG, Beveridge TJ, Flemming CA, Bailey GW (1989) Bacterial sorption of heavy metals. Appl Environ Microbiol 55(12):3143-3149

Müllner M, Hammel O, Mienert B, Schlag S, Bill E, Unden G (2008) A PAS domain with an oxygen labile $[4 \mathrm{Fe}-4 \mathrm{~S}](2+)$ cluster in the oxygen sensor kinase NreB of Staphylococcus carnosus. Biochemistry 47(52):13921-13932

Neubauer H, Götz F (1996) Physiology and interaction of nitrate and nitrite reduction in Staphylococcus carnosus. J Bacteriol 178(7): 2005-2009

Neubauer H, Pantel I, Götz F (1999) Molecular characterization of the nitrite-reducing system of Staphylococcus carnosus. J Bacteriol 181(5):1481-1488

Nguyen MT, Kraft B, Yu W, Demircioglu DD, Hertlein T, Burian M, Schmaler M, Boller K, Bekeredjian-Ding I, Ohlsen K, Schittek B, Götz F (2015) The nuSa alpha specific lipoprotein like cluster (lpl) of S. aureus USA300 contributes to immune stimulation and 
invasion in human cells. PLoS Pathog 11(6):e1004984. https://oi. org/10.1371/journal.ppat.1004984

Niemann V, Koch-Singenstreu M, Neu A, Nilkens S, Götz F, Unden G, Stehle T (2014) The NreA protein functions as a nitrate receptor in the staphylococcal nitrate regulation system. J Mol Biol 426(7): 1539-1553. https://doi.org/10.1016/j.jmb.2013.12.026

Niinivaara FP, Pohja MS (1956) Über die Reifung der Rohwurst. I Mitt: Die Veränderung der Bakterienflora während der Reifung. Zeitschrift für Lebensmittel Untersuchung und Forsch 104:413-422

Nilkens S, Koch-Singenstreu M, Niemann V, Götz F, Stehle T, Unden G (2014) Nitrate/oxygen co-sensing by an NreA/NreB sensor complex of Staphylococcus carnosus. Mol Microbiol 91(2):381-393. https:// doi.org/10.1111/mmi.12464

Nilvebrant J, Alm T, Hober S, Löfblom J (2011) Engineering bispecificity into a single albumin-binding domain. PLoS One 6(10):e25791. https://doi.org/10.1371/journal.pone.0025791

Nilvebrant J, Astrand M, Georgieva-Kotseva M, Bjornmalm M, Löfblom J, Hober S (2014) Engineering of bispecific affinity proteins with high affinity for ERBB2 and adaptable binding to albumin. PLoS One 9(8):e103094. https://doi.org/10.1371/journal.pone.0103094

Nord K, Gunneriusson E, Ringdahl J, Ståhl S, Uhlen M, Nygren PA (1997) Binding proteins selected from combinatorial libraries of an alpha-helical bacterial receptor domain. Nat Biotechnol 15(8):772777

Novick RP, Adler GK, Majumder S, Khan SA, Carleton S, Rosenblum WD, Iordanescu S (1982) Coding sequence for the pT181 repC product: a plasmid-coded protein uniquely required for replication. Proc Natl Acad Sci U S A 79(13):4108-4112

Otto M, O'Mahoney DS, Guina T, Klebanoff SJ (2004) Activity of Staphylococcus epidermidis phenol-soluble modulin peptides expressed in Staphylococcus carnosus. J Infect Dis 190(4):748-755

Pantel I, Lindgren PE, Neubauer H, Götz F (1998) Identification and characterization of the Staphylococcus carnosus nitrate reductase operon. Mol Gen Genet 259(1):105-114

Peschel A, Ottenwälder B, Götz F (1996) Inducible production and cellular location of the epidermin biosynthetic enzyme EpiB using an improved staphylococcal expression system. FEMS Microbiol Lett 137(2-3):279-284

Probst AJ, Hertel C, Richter L, Wassill L, Ludwig W, Hammes WP (1998) Staphylococcus condimenti sp. nov., from soy sauce mash, and Staphylococcus carnosus (Schleifer and Fischer 1982) subsp. utilis subsp. nov. Int J Syst Bacteriol 48(Pt 3):651-658

Rehm H-J, Omar SH (2001) Special morphological and metabolic behavior of immobilized microorganisms. In: Rehm H-J, Reed G. Biotechnology Set, 2nd edn. Wiley-VCH Verlag GmbH, Weinheim. https://10.1002/9783527620999.ch6

Robert A, Samuelson P, Andreoni C, Bachi T, Uhlen M, Binz H, Nguyen TN, Ståhl S (1996) Surface display on staphylococci: a comparative study. FEBS Lett 390(3):327-333

Rockberg J, Löfblom J, Hjelm B, Uhlen M, Ståhl S (2008) Epitope mapping of antibodies using bacterial surface display. Nat Methods 5(12):1039-1045. https://doi.org/10.1038/nmeth.1272

Rockberg J, Löfblom J, Hjelm B, Ståhl S, Uhlen M (2010) Epitope mapping using Gram-positive surface display. Curr Protoc Immunol Chapter 9:Unit9 9. https://doi.org/10.1002/0471142735. im0909s90

Rosenstein R, Götz F (2000) Staphylococcal lipases: biochemical and molecular characterization. Biochimie 82:1005-1014

Rosenstein R, Götz F (2010) Genomic differences between the foodgrade Staphylococcus carnosus and pathogenic staphylococcal species. Int J Med Microbiol 300(2-3):104-108. https://doi.org/10. 1016/j.ijmm.2009.08.014

Rosenstein R, Nerz C, Biswas L, Resch A, Raddatz G, Schuster SC, Götz F (2009) Genome analysis of the meat starter culture bacterium Staphylococcus carnosus TM300. Appl Environ Microbiol 75(3): 811-822. https://doi.org/10.1128/AEM.01982-08
Samuelson P, Hansson M, Ahlborg N, Andreoni C, Götz F, Bachi T, Nguyen TN, Binz H, Uhlen M, Ståhl S (1995) Cell surface display of recombinant proteins on Staphylococcus carnosus. J Bacteriol 177(6): 1470-1476

Samuelson P, Cano F, Robert A, Ståhl S (1999) Engineering of a Staphylococcus carnosus surface display system by substitution or deletion of a Staphylococcus hyicus lipase propeptide. FEMS Microbiol Lett 179(1):131-139

Samuelson P, Wernerus H, Svedberg M, Ståhl S (2000) Staphylococcal surface display of metal-binding polyhistidyl peptides. Appl Environ Microbiol 66(3):1243-1248

Samuelson P, Gunneriusson E, Nygren PA, Ståhl S (2002) Display of proteins on bacteria. J Biotechnol 96(2):129-154

Sandersjoo L, Jonsson A, Löfblom J (2015) A new prodrug form of Affibody molecules (pro-Affibody) is selectively activated by cancer-associated proteases. Cell Mol Life Sci 72(7):1405-1415. https://doi.org/10.1007/s00018-014-1751-8

Sandersjöö L, Jonsson A, Löfblom J (2017) Protease substrate profiling using bacterial display of self-blocking affinity proteins and flowcytometric sorting. Biotechnol J 12(1):1600365

Schlag S, Fuchs S, Nerz C, Gaupp R, Engelmann S, Liebeke M, Lalk M, Hecker M, Götz F (2008) Characterization of the oxygen-responsive NreABC regulon of Staphylococcus aureus. J Bacteriol 190(23): $7847-7858$

Schleifer KH, Fischer U (1982) Description of a new species of the genus Staphylococcus: Staphylococcus carnosus. Int J Syst Bacteriol 32: 153-156

Scouten WH (1995) Matrices and activation methods for cell adhesion/ immobilization studies. Bioprocess Technol 20:233-265

Sinha B, Francois P, Que YA, Hussain M, Heilmann C, Moreillon P, Lew D, Krause KH, Peters G, Herrmann M (2000) Heterologously expressed Staphylococcus aureus fibronectin-binding proteins are sufficient for invasion of host cells. Infect Immun 68(12):68716878

Ståhl S, Uhlen M (1997) Bacterial surface display: trends and progress. Trends Biotechnol 15(5):185-192. https://doi.org/10.1016/S01677799(97)01034-2

Ståhl S, Samuelson P, Hansson M, Andréoni C, Goetsch L, Libon C, Liljeqvist S, Gunneriusson E, Binz H, Nguyen TN, Uhlén M (1997) Development of non-pathogenic staphylococci as vaccine delivery vehicles. In: Pozzi G, Wells JM (eds) Gram-positive bacteria: vaccine vehicles for mucosal immunization. Springer, Berlin, pp $61-81$

Ståhl S, Graslund T, Eriksson Karlstrom A, Frejd FY, Nygren PA, Löfblom J (2017) Affibody molecules in biotechnological and medical applications. Trends Biotechnol. https://doi.org/10.1016/j. tibtech.2017.04.007

Strauss A, Götz F (1996) In vivo immobilization of enzymatically active polypeptides on the cell surface of Staphylococcus carnosus. Mol Microbiol 21(3):491-500

Sturmfels A, Götz F, Peschel A (2001) Secretion of human growth hormone by the food-grade bacterium Staphylococcus carnosus requires a propeptide irrespective of the signal peptide used. Arch Microbiol 175:295-300

Tanasupawat S, Hashimoto Y, Ezaki T, Kozaki M, Komagata K (1992) Staphylococcus piscifermentans sp. nov., from fermented fish in Thailand. Int J Syst Bacteriol 42(4):577-581

Tesch W, Strassle A, Berger-Bächi B, O'Hara D, Reynolds P, Kayser FH (1988) Cloning and expression of methicillin resistance from Staphylococcus epidermidis in Staphylococcus carnosus. Antimicrob Agents Chemother 32(10):1494-1499

Tibazarwa C, Corbisier P, Mench M, Bossus A, Solda P, Mergeay M, Wyns L, van der Lelie D (2001) A microbial biosensor to predict bioavailable nickel in soil and its transfer to plants. Environ Pollut 113(1):19-26 
Tiesinga JJ, van Pouderoyen G, Nardini M, Ransac S, Dijkstra BW (2007) Structural basis of phospholipase activity of Staphylococcus hyicus lipase. J Mol Biol 371(2):447-456. https:// doi.org/10.1016/j.jmb.2007.05.041

van Oort MG, Deveer AM, Dijkman R, Tjeenk ML, Verheij HM, de Haas GH, Wenzig E, Götz F (1989) Purification and substrate specificity of Staphylococcus hyicus lipase. Biochemistry 28(24):9278-9285

Voggu L, Schlag S, Biswas R, Rosenstein R, Rausch C, Götz F (2006) Microevolution of cytochrome $b d$ oxidase in staphylococci and its implication in resistance to respiratory toxins released by Pseudomonas. J Bacteriol 188(23):8079-8086

Volk AL, Hu FJ, Berglund MM, Nordling E, Stromberg P, Uhlen M, Rockberg J (2016) Stratification of responders towards eculizumab using a structural epitope mapping strategy. Sci Rep 6:31365. https://doi.org/10.1038/srep31365
Wenzig E, Lottspeich F, Verheij B, De Haas GH, Götz F (1990) Extracellulare processing of the Staphylococcus hyicus lipase. Biochem (Life Sci Adv) 9:47-56

Wernerus H, Ståhl S (2002) Vector engineering to improve a staphylococcal surface display system. FEMS Microbiol Lett 212(1):47-54

Wernerus H, Lehtio J, Teeri T, Nygren PA, Ståhl S (2001) Generation of metal-binding staphylococci through surface display of combinatorially engineered cellulose-binding domains. Appl Environ Microbiol 67(10):4678-4684

Wernerus H, Samuelson P, Ståhl S (2003) Fluorescence-activated cell sorting of specific affibody-displaying staphylococci. Appl Environ Microbiol 69(9):5328-5335

Wieland KP, Wieland B, Götz F (1995) A promoter-screening plasmid and xylose-inducible, glucose-repressible expression vectors for Staphylococcus carnosus. Gene 158:91-96 